\title{
NOTES ON THE CUPRESSACEAE IN VIETNAM
}

\section{KEITH RUSHFORTH}

The Shippen, Ashill, Cullompton, England, EXI5 3NL

\section{SUMMARY}

The taxonomy of the species of Cupressaceae indigenous to Vietnam is reviewed. Cupressus tonkinensis Silba is considered the correct name for the Cupressus in Langson province, not Cupressus torulosa. The genus Xanthocyparis is reduced to a subgenus of Cupressus and the new combination Cupressus vietnamensis (Farjon \& Hiep) Rushforth made. The genus Fokienia is not considered separable from Chamaecyparis and the combination Chamaecyparis hodginsii (Dunn) Rushforth is made. The conifers associated with Cupressus vietnamensis and their conservation are discussed.

Key words: Cupressus; Xanthocyparis; Chamaecyparis; Fokienia; Cupressus tonkinensis; Cupressus vietnamensis; Chamaecyparis hodginsii.

The Cupressaceae is now considered by some authorities to include the Taxodiaceae [7] whilst other treatments [15] maintain the two families as separate phylogenetic lines. My personal opinion is to consider the Cupressaceae in the traditional sense but to question whether Hayata's treatment (1932) of the Taxodiaceae as several distinct lineages may not be the most coherent approach - the main difference between Quinn's treatment in $G$ adek et al. (2000) and Hayata's treatment is in the level of the units - Hayata has separate families, Quinn has subfamilies of Cupressaceae sensu lato. This paper concerns only the members of the Cupressaceae sensu stricto - Cupressoideae Richard ex Sweet (Hortus Britannica: 372, 1826).

Four members of the Cupressoideae are found in indigenous natural forest in Vietnam. These have been treated as belonging to the genera Calocedrus, Cupressus, Fokienia and Xanthocyparis. Some others are cultivated, such as Cupressus arizonica Greene at Dalat and Platycladus orientalis (L.f.) Franco at Hanoi.

\section{Cupressus in Langson province}

In 1919 Philippe Eberhardt collected material from a tree 8-10 $\mathrm{m}$ in height growing at 32
Kaikinh in Langson province, Vietnam; the collection was numbered 5073 and his specimens are lodged at Paris (P) and New York (NY). Chevalier (1919) identified it as Cupressus funebris Endl. Silba (1994, 1998) described this material as a new species, Cupressus tonkinensis. He designated the NY specimen as the holotype and the $\mathrm{P}$ specimen as the isotype. Other authorities (e.g. Farjon 1998, p 45) have considered Cupressus tonkinensis to be a synonym of Cupressus torulosa D. Don, a species otherwise known only from the western Himalaya from central Nepal to northwest India and adjacent southwestern Tibet (Xizang). Luu \& Thomas (2004), however, considered it to be a synonym of Cupressus funebris, though they expressed one or two reservations; they concluded that it was definitely not a synonym of Cupressus torulosa. Through the courtesy of the Curator of the Herbarium at the Royal Botanic Garden Edinburgh (E), I have been able to borrow the Paris isotype and see a photograph of the NY specimen. I have compared the Paris isotype with all the material of Cupressus torulosa in the Edinburgh herbarium. My observations relate specifically to the Paris isotype, although the photograph of the NY holotype appears to be the same. Both specimens are very fragile and fragmented. 
The Paris isotype contains both foliage and one-year cones (the photograph of the holotype shows only foliage).

The cones are almost round and have 8 scales (4 pairs of decussate scales), each scale with a small prickle-like umbo.

The foliage on the most recent growths contains some shoots which are terete (round as in a cylinder); on these shoots the decussate pairs of leaves are indistinguishable. However, most foliage is in flattened shoots with dimorphic leaves; on these shoots the facial (Facial leaves are those facing you when a spray is laid flat) leaves have an obvious dorsal gland and are rhombic in shape; the laterals (Lateral leaves are those at the side when a spray is laid flat) are adpressed with a blunt rounded tip of $0.5 \mathrm{~mm}$ with only a weakly defined gland.

I examined the following material of Cupressus torulosa in the Edinburgh herbarium:

Page 10715. Mussoorie Hill Station, India; Walter Koelz 20354. United Provinces, India; R. E. Cooper 5793. Jheri Kulu, Punjab, India; Stewart s.n. North West India; A. Anderson s.n.. Mussoorie, India; Stainton 7593. Mazana Kulu, Himachal Pradesh, India; Blinkworth ( $\mathrm{Hb}$. Wallich 6046B), Kumaon, North West India; G. Watt s.n. Thula, India; Hooker \& Thomson, s.n.. Simla, India; Noshiro et al. 9455337 and 9455353. Dhawalagiri, Mustang, Central Nepal; Minaki et al. 9106095. Karnali, Dolpa, West Nepal; Stainton, Sykes \& Williams 3273. Maikot, Nepal; Stainton, Sykes \& Williams 1673. Tajlung, South of Tukucha, Kali Gandaki, Central Nepal; Stainton, Sykes \& Williams 726. Larjung, South of Tukucha, Kali Gandaki, Central Nepal; J. R. Reid s.n. Nainital (India: Uttaranchal); F. M. Bailey s.n. Chaha, West Nepal.

This material of Cupressus torulosa differs from the Paris specimen of Eberhardt 5073 in the following characters:

The cones (when present) have 10, occasionally 12 scales (i.e. 5, occasionally 6 , pairs of scales); the scales in the one year cones (when present) have an umbo which is a prominent prickle making these cones spiky, not rounded; however in mature (two year old) and older cones the umbo becomes eroded, making the cones rounded in outline. The ultimate shoots are radially symmetrical with no differentiation into facial and lateral leaves and the sprays are three-dimentional, never in twodimentional or flattened sprays. The foliage on the material of Cupressus torulosa is either smooth rounded (terete) or coarse rope-like with rough regular projections; the coarse rope-like foliage appears to be correlated with the drier inner-valley habitats and the terete foliage with the moister outer ranges.

The above considerations shows that Cupressus tonkinensis is clearly not referable to Cupressus torulosa, differing in the cones with only 8 (cf. 10-12) scales and in the mainly flattened foliage (cf. rounded) with distinct facial and lateral leaves. Taken with the geographical separation - from Laos to Sikkim! - Cupressus tonkinensis warrants specific status and is not a synonym of Cupressus torulosa.

Cupressus tonkinensis can be distinguished from Cupressus funebris - on the basis of the limited material available - by the foliage of C. tonkinensis being in flattened and sparse fan-shaped sprays and not in the long pendulous sprays which characterise Cupressus funebris. Also, the lateral leaves on the Paris isotype have blunt, adpressed tips, not the acute translucent tips to the lateral leaves of Cupressus funebris, and the glands on the facial leaves are more pronounced than in typical Cupressus funebris. The number of cone scales in Cupressus funebris ranges from 6-10, thus straddling the range of Cupressus tonkinensis.

Silba has cited two specimens at the Arnold Arboretum from Guizhou, China as belonging to Cupressus tonkinensis, viz. Y. Tsiang 8004 and Steward, Chiao \& Cheo 10. Through the good offices of the two Curators, I have borrowed these and examined them at Edinburgh; they both fall within the range of Cupressus funebris and are not close to Cupressus tonkinensis. Cupressus tonkinensis is, on our current knowledge, a Vietnamese endemic.

At Huulung in Langson province $\left[21 \square 40^{\prime} 42^{\prime \prime} \mathrm{N}, 106 \square 22^{\prime} 42^{\prime \prime} \mathrm{E}\right]$ at $220 \mathrm{~m}$ there is a grove of circa twenty trees. These were planted in the late 1980's; the seed is reported to have been collected from a tree or trees growing on 
the nearby karst limestone peaks; other trees are also cultivated in gardens in the vicinity. These trees are not fully mature but the adult foliage has the flattened sparse sprays of Cupressus tonkinensis. However, the tips of most of the lateral leaves are acute with a short incurved mucro; some leaves, however, have the blunt incurved tips characteristic of Cupressus tonkinensis.

My opinion is that the foliage of these trees, which are only about 15 years old, is in an intermediate stage between fully juvenile foliage (where the leaves are in whorls of four with the two decussate pairs superimposed) and fully adult. I consider (on the currently available information) that the Huulung trees are Cupressus tonkinensis.

Interestingly the Huulung trees have both adult (semi-adult?) and juvenile foliage on the same branches. Retained juvenile foliage seems to be a feature of Eastern Asian Cupressaceae. It is common for a decade or more on plants of Cupressus funebris and Cupressus chengiana $\mathrm{S}$. $\mathrm{Y}$. Hu and the genus Retinospora Sieb. \& Zucc. was named for juvenile forms of Japanese Chamaecyparis. However, this neatly leads into the Quanba cypress.

\section{Quanba cypress in Hagiang province}

A cypress was found growing on the karst limestone ridges just to the east of Quanba in Hagiang province in 1999. This tree shows considerable similarities to Nootka cypress which is found in western North America from northern California to southern Alaska and clearly the two species belong to the same genus. Historically Nootka cypress has been variously treated as Cupressus nootkatensis D. Don or Chamaecyparis nootkatensis (D. Don) Spach, but recently the consensus had been moving in favour of Cupressus both on appraisals based on morphological characters [6] and on molecular data [7].

The genus Xanthocyparis Farjon \& Hiep has been proposed for both Nootka cypress and the Quanba species (as Xanthocyparis vietnamensis Farjon \& Hiep). Recent molecular work (Adams, pers. comm., Wang et al. [2003]) have shown Nootka cypress and the Quanba cypress nested within Cupressus, thus confirming the view expressed by Gadek et al. (2000). Little et al. (2004) have also shown both Nootka and Quanba cypresses as nested within a Cupressus clade including Juniperus, but have noted that the genus Callitropsis Orsted (non Compton) has priority over Xanthocyparis. Molecular work has also shown that Fokienia is nested within Chamaecyparis (Gadek et al., 2000, Little et al. 2004, Adams, pers. comm.). It is worth listing the principal characters of these genera to see whether there are one, two, three or four genera.

\begin{tabular}{|c|c|c|c|c|}
\hline & Cupressus & $\begin{array}{c}\text { Callitropsis } \\
\text { (Xanthocyparis) }\end{array}$ & Chamaecyparis & Fokienia \\
\hline Leaves & $\begin{array}{l}\text { Either dimorphic } \\
\text { or adpressed, } \\
\text { rarely retain } \\
\text { juvenile }\end{array}$ & Dimorphic & Usually dimorphic & Dimorphic \\
\hline Male cones & $\begin{array}{c}6-16 \\
\text { microsporangia } \\
2-6 \text { pollen sacs }\end{array}$ & $\begin{array}{c}10-16 \\
\text { microsporangia } \\
\text { 2(-3) pollen sacs }\end{array}$ & $\begin{array}{c}6-8 \\
\text { microsporangia } \\
2-4 \text { pollen sacs }\end{array}$ & $\begin{array}{c}(6-) 10-12 \\
\text { microsporangia } \\
3 \text { pollen sacs }\end{array}$ \\
\hline $\begin{array}{l}\text { Female } \\
\text { cones }\end{array}$ & $\begin{array}{l}\text { Open } 2^{\text {nd }} \text { year } \\
(6-) 8-6 \text { scales }\end{array}$ & $\begin{array}{c}\text { Open } 2^{\text {nd }} \text { year } \\
4-6 \text { scales }\end{array}$ & $\begin{array}{l}\text { Open first year } \\
8-12 \text { scales }\end{array}$ & $\begin{array}{c}\text { Open } 2^{\text {nd }} \text { year? } \\
12-16 \text { scales }\end{array}$ \\
\hline $\begin{array}{l}\text { Female cone } \\
\text { scales }\end{array}$ & peltate & $\begin{array}{c}\text { Valvate to sub- } \\
\text { peltate }\end{array}$ & Peltate & Peltate \\
\hline Seeds & 3 - 20 per scale & 1 - 3 per scale & $\begin{array}{c}(1-) 2(-5) \text { per } \\
\text { scale }\end{array}$ & 2 per scale \\
\hline Seed wings & $\begin{array}{c}2 \text { narrow lateral } \\
\text { wings }\end{array}$ & $\begin{array}{l}2 \text { thin or narrow } \\
\text { lateral wings }\end{array}$ & $\begin{array}{c}2 \text { narrow lateral } \\
\text { wings }\end{array}$ & $\begin{array}{l}2 \text { unequal wings } \\
1 \text { may be narrow }\end{array}$ \\
\hline
\end{tabular}


This tabulation shows that Callitropsis (Xanthocyparis) falls within the range of variation of Cupressus except for four characters: the number of cones scales is at the bottom end of the range of Cupressus; the number of ovules per fertile scale is also at the bottom of the range of Cupressus and the scales are valvate to sub-peltate (c.f. peltate). The seeds of the Quanba cypress have two thin lateral wings but those of Nootka cypress have narrow lateral wings (as in Cupressus). Callitropsis (Xanthocyparis) differs from Chamaecyparis in the greater number of microsporangia (10-16, cf. 6-8); the cones maturing in the second year with only 4-6 (cf. 812) scales which are valvate to sub-peltate (cf. peltate).

My opinion is that the species assigned to Callitropsis (Xanthocyparis) are not sufficiently distinct to be defined as a genus but fit within the range of variation of Cupressus. However, I consider that subgeneric status is justified, due to the number of cone scales and ovules (seeds) per scale being at the bottom of the range for Cupressus and the scales being valvate to subpeltate (cf. peltate) and propose to use the Xanthocyparis name for the subgenus. I do not consider that the retained juvenile foliage is a generic character - this is an adaptation to the specific conditions and occurs in diverse genera in different parts of the world.

Little et al. (2004) have both Callitropsis (Xanthocyparis) and Juniperus nested within Cupressus but with different clades of Cupressus for Old World and New World species. They suggest the possibility that the nesting of Juniperus within Cupressus may require the separation of Cupressus into two separate genera. However, the residual markings of the scales on the cone of Juniperus chinensis L. has suggested that the genus was derived from Cupressus. Further proof of the validity of this suggestion will not necessarily require the splitting of Cupressus into separate genera.

The subsumation of Callitropsis (Xanthocyparis) in Cupressus requires the following new combinations:

Cupressus L. subgenus Xanthocyparis (Farjon \& Hiep) Rushforth, comb. et stat. nov.
Basionym Xanthocyparis Farjon \& Hiep in Farjon, Hiep, Harder, Loc \& Averyanov, Novon 12(2):179, 2002. TYPE: Cupressus vietnamensis (Farjon \& Hiep) Rushforth.

Cupressus vietnamensis (Farjon \& Hiep) Rushforth, comb. nov. Basionym: Xanthocyparis vietnamensis Farjon \& Hiep in Farjon, Hiep, Harder, Loc \& Averyanov, Novon, 12(2): 180, 2002. Callitropsis vietnamensis (Farjon \& Hiep) D. P. Little in Little, D. P., A. E. Schwarzbach, R. P. Adams \& C-F. Hsieh, Amer. J. Bot. 91(11): 1879 (2004).TYPE: Vietnam. Hagiang: Quanba, Bat Dai Son, Bat Dai Son Protected Area, 10th February 2001, D. K. Harder, N. T. Hiep, P. K. Loc, L. V. Averyanov, G. E. Schatz \& S. Bodine DKH 6091 (holotype HN, isotypes $\mathrm{MO}, \mathrm{K}, \mathrm{LE}$ ).

Cupressus $\times$ notabilis (A. F. Mitchell) Rushforth, comb. nov. Basionym $\times$ Cupressocyparis notabilis A. F. Mitchell, J. Roy. Hort. Soc. 95(10): 453. 1970. TYPE: England. Hampshire: Alice Holt Lodge, 31st July 1963, Mitchell s.n. (holotype, K [not seen]).

Cupressus $\times$ ovensii (A. F. Mitchell) Rushforth, comb. nov. Basionym $\times$ Cupressocyparis ovensii A. F. Mitchell, J. Roy. Hort. Soc. 95 (10): 454. 1970. TYPE: England. Hampshire: Alice Holt Lodge, 1970, s.d., Mitchell s.n. (holotype, K [not seen]).

Both $\times$ Cupressocyparis Dallimore \& A. B. Jackson (Forestry 11: 3. 1937) and $\times$ Cuprocyparis Farjon (Novon 12: 188. 2002) become syn. nov. of Cupressus L.

The habitat of the karst limestone ridges at Quanba is extraordinary. The discussion on ecology of Cupressus vietnamensis in Farjon et al. (2002) gives some idea of the range of associated plants. However, it does not give a full list of the conifers found on these ridges, and misidentifies some of those listed. Apart from Cupressus vietnamensis, there are:

Amentotaxus argotaenia (C. Presl) Kuntze which forms an understorey shrub. A specimen from this area but lacking the narrow but bright stomatal bands has been described as Amentotaxus hatuyenensis but is unlikely to be worthy of recognition. 
Pinus wangii $\mathrm{Hu} \& \mathrm{~W}$. C. Cheng is a five needled or soft pine which is otherwise known only from nearby southeast Yunnan.

Nageia fleuryi (Hickel) de Laub.. This has been confused with Nageia wallichiana (C. Presl) Kuntze which occurs in Cucphuong national park. The easiest key character is that the leaves of Nageia wallichiana have stomatal lines on both surfaces, whereas in Nageia fleuryi they are only found on the lower surface (stomata are not very obvious even with a hand lens!).

Pseudotsuga brevifolia W. C. Cheng \& L. $\mathrm{K} . \mathrm{Fu}$ is sometimes treated as a variety of Pseudotsuga sinensis Dode (as var. brevifolia (Cheng \& Fu) Farjon \& Silba) but is easily separated by the shorter and broader leaves; Podocarpus wangii C. C. Chang. This species may be synonymous with Podocarpus pilgeri Foxw. from Indonesia, Papua New Guinea and the Philippines; Tsuga chinensis (Franch.) E. Pritz.. It is interesting that this appears to represent the most southerly occurrence of this species (although, as I have not seen cones, I cannot entirely eliminate the possibility that the tree could be Nothotsuga longibracteata (W. C. Cheng) $\mathrm{Hu}$ ex C. N. Page (syn. Tsuga longibracteata W. C. Cheng). Tsuga dumosa (D. Don) Eichler is found on the Hoanglienson range north of Fansipan above the village of Bankhoang in Laocai province and is the most easterly occurrence of this otherwise Himalayan species.

Taxus wallichiana Zucc. aggregate. At present it seems more sensible to use the predominant aggregate name, rather than Taxus chinensis (Pilg.) Rehd. or Taxus mairei Lemée \& Léveill é. The species is clearly not the same as the one from Lamdong province in the south of Vietnam which has also been called Taxus wallichiana, but may be closer to Taxus sumatrana (Warb.) de Laub.

The conservation of these trees is a priority, but the needs of the local H'mong people for timber and forest products also needs considering. A particular difficulty is that trees like Pseudotsuga brevifolia and Pinus wangii will become useful timber trees before they are sufficiently mature to cone. Thus there is a risk that the adult population will be harvested, leaving no parent trees to provide the next generation. Preventing any felling or harvesting is unlikely to succeed; also just protecting the area is unlikely to be successful because the habitat is so restricted there is a risk that species will be lost by random failure to regenerate. Perhaps a way around this conundrum would be for a certain minimum number of trees, perhaps 50 of each species in a given area, to be marked and their felling only permitted when two replacement trees can be identified.

\section{Fokienia or Pémou}

Molecular investigations have shown that Fokienia clusters with Chamaecyparis [7, 10]. In the paper by Gadek et al. (2002), it is only in the cladogram based on non-molecular data that Fokienia is not sister to Chamaecyparis; this cladogram (fig. 4 in Gadek et al., 2002) is odd in some other associations, such as Neocallitropsis with Taiwania. In the paper by Little et al. (2004) the cladogram derived from the ITS (nrDNA) showed Fokienia neatly nested within Chamacyparis, between Chamaecyparis lawsoniana (Murray) Parlatore and Chamaecyparis pisifera (Sieb. \& Zucc.) Endl.. However, when other data, including morphological data was used, Fokienia came out as a sister group to Chamaeyparis. If the molecular data is strongly clustering Fokienia with Chamaecyparis, it questions the validity of the non-molecular characters used to separate the two genera.

Dunn (1908) first described Fokienia hodginsii but as a species belonging to Cupressus section Chamaecyparis. It was Henry \& Thomas (1911) who proposed the genus Fokienia. They compared it with Chamaecyparis lawsoniana and Calocedrus macrolepis Kurz. Henry \& Thomas's Latin diagnosis for Fokienia reads "genus novum Cupressinearum, inter Libocedrum et Cupressum collocandum; strobili globosi, squamae peltatae, quam in Cupresso section Chamaecyparis, sed dispermae; semina bialata, alis lateralibus valde inaequalibus, quam in Libocedro; folia et habitus Libocedri macrolepidis. Species unica, Fokienia hodginsii 
Henry et Thomas. "This can be paraphrased as 'cones like Chamaecyparis but with only two seeds, seed wing (and foliage) like Calocedrus macrolepis' - Calocedrus macrolepis is easily separated by the oblong cones with valvate scales hinged at the base. In the English discussion Henry \& Thomas suggested that the seed wing was derived from the cone scale, not integral with the ovule, and that the cones took two years to ripen.

But do these characters hold good, and are they sufficient to justify a separate genus for Fokienia?

The character of two ovules per scale "squamae $\square$ dispermae" - does not separate Fokienia from Chamaecyparis. Henry (in Elwes \& Henry, 1910, p 1149 [in the publication Chamaecyparis is only treated as a section of Cupressus]) had given for Chamaecyparis "Seeds one to five on each scale" and gives "Seeds two to five on each scale" for Chamaecyparis lawsoniana (notwithstanding Henry \& Thomas (1911) citing three ovules for Chamaecyparis lawsoniana) and "one to two" (sic, surely he meant one or two!) for both Chamaecyparis pisifera and Chamaecyparis thyoides (L.) Britton et al. and "two" for Cupressus nootkatensis D. Don.

The wings on the seeds of Fokenia are more pronounced than in any other Chamaecyparis or Cupressus, and resemble those of Calocedrus. However, it is unclear that this is a generic character. In Pinus, there are species in the same section of the genus with either rudimentary rim-like wings or large functional wings. In Betula, different parts of the genus may have large wings a single cell in thickness or short, rim-like wings several cells thick. In Cupressus Little et al. (2004, p. 1875) note variation, e.g. with the wings of some species being "highly reduced". In short, I do not see this as a generic character.

The cones allegedly taking two years to ripen is at variance with Chamaecyparis as generally treated today. However, I have observed Fokienia in China and Vietnam and in cultivation in England and examined the material at Edinburgh. In Yunnan and northern Vietnam I have observed the conelets reaching anthesis during the autumn but the actual time of anthesis may be variable depending upon climate - otherwise I must question the accuracy of the statement by $\mathrm{Fu}, \mathrm{Yu} \&$ Farjon in $\mathrm{Wu} \&$ Raven (Flora of China, 4: 69, 1999) that pollination time is March-April. Apart from conelets around anthesis, I have only seen, either on a living tree or in herbaria, mature autumn cones, not an intermediate one-year conelet, as seen in Cupressus or Pinus.

I have examined the following material of Fokienia in the Edinburgh herbarium: R. C. Ching 2345, King Yuan, Zhejiang, China; R. C. Ching 2361, ibid; Hodgins, s.n., Foochow, Fujian, China; J. Linsley Gressit 1740, Tai Yang, Guangdong, China; Luo Lin-bo 1231, Xining County, Hunan, China; J. Esquirol 2091, Tuy-sey-kiao, Guizhou, China; Y. Tsiang 7135, Ping Chow, Guizhou, China; Y. Tsiang 8867, without precise locality, Guizhou, China; E.E. Maire 75, Tie-Tchang-Keou, Yunnan, China; J. Cavalerie 7663, Kunming (Yunnan-sen), Yunnan, China; K. Rushforth 7460, Kunming Botanic Garden, Kunming, Yunnan, China; K. Rushforth 137, Baoguoxi, Emei Shan, Sichuan, China; W. T. Tsang 27297, Taai Wong Mo Shan, Chuk-phai, Ha-coi, Vietnam; K. Rushforth 3073, Fanxipan, ridge above Sinchay, Sapa, Laocai, Vietnam; Gardner, Thomas \& Luu 20, Nam Qua river, Liemphu, Vanban district, Laocai, Vietnam; Gardner, Thomas \& Luu 26, route to Ta Xa mountain, Liemphu, Vanban district, Laocai, Vietnam; S. Ickert-Bond, R. Bond, Hiep \& Phan Ke Loc 202, Paco, Maichau district, Hoabinh, Vietnam; Poilane 6527, Massif de la Mère et l'Enfant, north of Ninhhoa, Nhatrang, Khanhhoa, Vietnam; N. D. T. Luu \& N. V. Chi 2, Honchang, Phuocbinh, NinhtThuan, Vietnam; N. D. T. Luu \& N. V. Chi 234, Bidoup, Lacduong, Lamdong, Vietnam; N. D. T. Luu \& N. V. Chi 235, ibid.; N. D. T. Luu \& N. V. Chi 236, ibid.

My observations lead me to the conclusion that the cones ripen in the autumn following anthesis, and thus do not take two years to mature. In this context it is interesting to note that Gadek et al. (2000) for their non-molecular character 44 "Seed maturation: in the first year; in the second year or later" have both Chamaecyparis and Fokienia as maturing in the 
first year. However, as their analysis includes Cupressus nootkatensis within Chamaecyparis, this may merely be an error on their part.

The characters given in the above table show Fokienia either within the range recorded for Chamaecyparis (e.g. number of microsporangia and pollen sacs) or overlapping (e.g. number of cones scales in the female cone).

Gadek et al. (2000) (if we exclude Cupressus nootkatensis) give only three nonmolecular characters to separate Chamaecyparis and Fokienia (see Figure 5). These are "5. Transverse walls of vertical parenchyma with small nodules (Chamaecyparis); with large nodules (Fokienia)", "27. Accumulation of nootkatin in the heartwood: absent (Fokienia); present (Chamaecyparis)" and "36. Number of ovules per cone scale: two (Fokienia); more than two (Chamaecyparis)". The last character clearly does not separate Fokienia and Chamaecyparis, and is not correct for Chamaecyparis. The other two characters, if correct (and only two species of Chamaecyparis feature in their analysis, which does not include the type species, Chamaecyparis thyoides, do not warrant separate generic status for Fokienia.

I conclude, therefore, that the morphological characters do not adequately differentiate Fokienia from Chamaecyparis and consider, as indicated by molecular data, that the genus Fokienia is not distinct from Chamaecyparis.

The following new combination is required in Chamaecyparis Spach:

Chamaecyparis hodginsii (Dunn) Rushforth, comb. nov. Basionym Cupressus hodginsii Dunn, J. Linn. Soc. Bot. 38: 367, 1908. Syn. nov. Fokienia hodginsii (Dunn) A. Henry \& H. H. Thomas, Gard. Chron., ser. 3, 49:67, 1911. TYPE: China, Fujian, woods about Yenping at 2000 feet $(600 \mathrm{~m}), \mathrm{S}$. T. Dunn 3505 (holotype Hongkong Herb. [non vidi]).

I do not see any justification for treating Fokienia kawaii Hayata $(=F$. hodgsinii var. kawaii (Hayata) Silba) and Fokienia maclurei Merrill as other than synonyms of Chamaecyparis hodginsii.

The treatment of Fokienia as part of Chamaecyparis resolves one botanical 38 conundrum - why is Chamaecyparis absent from the east Asian mainland when it occurs on Japan and Taiwan with no less than two species each. Various authorities have attempted to resolve the issue, such as Wang et al. (2003) suggesting an offshore migration from North America to Japan and Taiwan bypassing the Asian mainland (but unfortunately did not include Chamaecyparis hodginsii in their analysis), and others have postulated Cupressus funebris as belonging to Chamaecyparis and thus being the missing mainland species. However, treating Dunn's species as Chamaecyparis hodginsii resolves the issue this is basically Dunn's treatment, it is just that he subsumed Chamaecyparis in Cupressus.

Chamaecyparis hodginsii has a distribution from Zhejiang and Fujian across to southeast Sichuan and then south to Lamdong and Ninhthuan provinces in southern Vietnam. In Vietnam it occurs in warm temperate to subtropical montane forest.

Acknowledgements: I would like to thank the Curators of the Herbaria at Edinburgh, Paris and the Arnold Arboretum for access to their collections. I would also like to thank $\mathrm{Dr} \mathrm{H}$. McAllister and an anonymous reader for comments upon the text, and Dr Tran Cong Khanh and Do Thuy Linh.

\section{BIBLIOGRAPHY}

1. Chevalier A., 1919: Bull. Écon. Indochine. New ser., 137: 165-166.

2. Dunn S. T., 1908: J. Linn. Soc., Bot., 38: 367.

3. Elwes H. J. \& A. H. Henry, 1910: The Trees of Great Britain and Ireland. Volume 5. Edinburgh.

4. Farjon A., 1998: World Checklist and Bibliography of Conifers. Royal Botanic Gardens, Kew.

5. Farjon A. et al., 2002: A new Genus and Species in Cupressaceae (Coniferales) from Northern Vietnam, Xanthocyparis vietnamensis. Novon, 12: 179-189.

6. Frankis M. P., 1993: Conif. Soc. Austral. Newslett., 12: 9-10. 
7. Gadek P. A. et al., 2000: Amer. J. Bot., 87(7): 1044-1057.

8. Hayata B., 1932: Bot. Mag. (Tokyo), 96 (541): 24-27.

9. Henry A. \& H. H. Thomas, 1911: Gard. Chron., ser. 3: 49: 67.

10. Liitle D. P. et al., 2004: Amer. J. Bot., 91(11): 1872-1881.

11. Luu N. D. T. \& P. I. Thomas, 2004: Cây lá kim Việt Nam. Nxb. Thế Giới.
12. Silba J., 1994: J. Int. Conif. Preserv. Soc., 1(1): 23.

13. Silba J., 1998: J. Int. Conif. Preserv. Soc., 5(2): 38 .

14. Wang W. P. et al., 2003: Pl. Syst. Evol, Suppl., 241: 13-28.

15. Fu L. G., Y. F. Yu and A. Farjon, 1999: Cupressaceae: 62-77. Flora of China Vol. 4. Science Press, Beijing and Missouri Botanical Garden Press, St. Louis.

\section{GHI CHÉP VỀ HO CUPRESSACEAE Ở VIÊT NAM}

\section{KEITH RUSHFORTH}

\section{TÓM TẮT}

Bài viết đề cập đến phân loại các loài bản địa trong họ Cupressaceae ở Việt Nam. Trước đây, một loài thuộc chi Cupressus ở tỉnh Lạng Sơn vẫn được xác định là Cupressus torulosa, nhưng nay tên đúng của nó là Cupressus tonkinensis Silba. Chi Xanthocyparis được chuyển thành một phân chi của Cupressus và thành lập một tổ hợp tên mới là Cupressus vietnamensis (Farjon \& Hiep) Rushforth. Chi Fokienia không tách khỏi chi Chamaecyparis nên thêm một tổ hợp tên mới là Chamaecyparis hodginsii (Dunn) Rushforth. Bài viết cũng bàn về bảo tồn các loài thông và hoàng đàn ở Việt Nam.

Ngày nhận bài: 13-3-2007 